\title{
Sixth Disease (Roseola Infantum, Exanthem Subitum)
}

\author{
Altıncı Hastalık (Roseola Infantum, Ekzantem Subitum)
}

\author{
Ergin Çiftçi(iD) \\ Division of Pediatric Infectious Diseases, Department of Pediatrics, Ankara University Faculty of Medicine, Ankara, Turkey
}

Cite this article as: Çiftçi E. Sixth disease (roseola infantum, exanthem subitum). J Pediatr Inf 2021;15(3):e200.

A nine-month-old male patient was brought with complaints of fever and restlessness. It was learned that the patient lived only with his parents and did not come into contact with anyone who was sick recently. The patient had never had a fever, had no history of antibiotic use, and had been fully vaccinated according to his age. The patient's body temperature was measured as $38.4^{\circ} \mathrm{C}$, no pathological finding was detected except for oropharyngeal hyperemia. The patient's complete blood count, C-reactive protein and urine examination were within normal limits, and there was no growth in blood and urine cultures. It was said that the patient might be suffering from sixth disease, that the fever may last for a few more days, that the fever may decrease and the rash may appear. In the follow-up of the patient, who was followed up with paracetamol, the fever decreased on the fifth day and maculopapular rashes, which were more prominent on the trunk, appeared. The patient was active and cheerful in the control examination. The parents were told that there was no need for antipyretic administration and laboratory examination after that. The patient's rash faded spontaneously within three days. No problem was observed in the follow-up.

Sixth disease is a worldwide common childhood disease caused by infection with human herpesvirus 6 (HHV-6) or, less frequently, human herpesvirus 7 (HHV-7). Also known as roseola infantum or exanthema subitum, sixth disease occurs most often in young children between the ages of
6 months and 2 years. Sixth disease is the leading cause of non-vaccine-related first febrile illness in previously healthy children who do not have much contact with other people. The disease begins with an acute onset of high fever lasting 3 to 5 days. Seizures can be seen in some children during the febrile period. With the rapid decrease of fever, a nonpruritic, pink-colored maculopapular rash appears on the trunk. The sixth disease, the causative agent of which remains latent in healthy children, is a clinically diagnosable, self-limiting and symptomatically treatable disease.

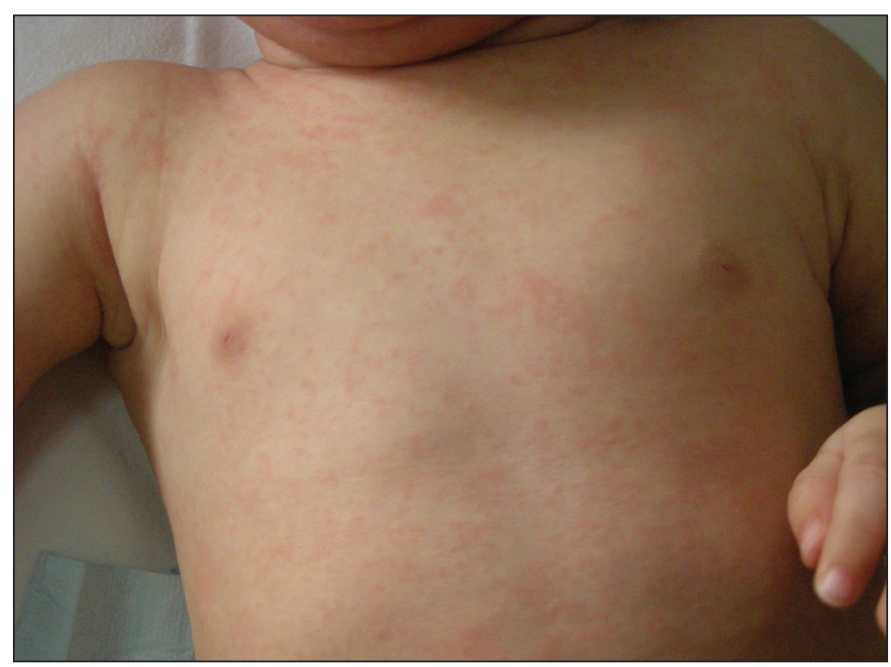

\section{Correspondence Address/Yazışma Adresi}

Ergin Çiftçi

Ankara Üniversitesi Tıp Fakültesi,

Çocuk Sağlığı ve Hastalıkları Anabilim Dalı,

Çocuk Enfeksiyon Hastalıkları Bilim Dalı,

Ankara-Türkiye

E-mail: erginciftci@gmail.com 